\title{
Difficult-to-control secondary hypertension in a patient with history of glioblastoma, and cerebral edema — a case study
}

\author{
Małgorzata Placek*1, Marta Soltysiak ${ }^{* 1}$, Jacek Drozdowski', Jacek Wolf ${ }^{2}$ \\ ${ }^{1}$ Department of Internal Diseases with Hypertension Unit, Copernicus Municipal Hospital, Gdańsk, Poland \\ ${ }^{2}$ Department of Hypertension and Diabetology, Medical University of Gdańsk, Gdańsk, Poland \\ *both authors equally contributed
}

\begin{abstract}
We report a history of a patient with difficult-to-control high blood pressure, central nervous system mass and several comorbidities which altogether made the blood-lowering medication particularly challenging. Patient was diagnosed with glioblastoma, renovascular stenosis to a single kidney, and cerebral edema resulting from both cerebral tissue mass and exceedingly high systemic blood pressure. In the presented case we faced several contraindications to the guideline-recommended treatment with RAAS blockers, beta-blockers, and several diuretic classes which were determined by (1) the only remaining kidney's renal artery stenosis, (2) decreased creatinine clearance and (3) reflex bradycardia secondary to cerebral edema. Evidence-based recommendations do not clarify all clinical aspects related to emergent high blood pressure because the evidence is sparse; therefore, we found it interesting to share our experience.
\end{abstract}

Key words: secondary hypertension; renovascular hypertension; chronic kidney disease; cerebral edema; glioblastoma; hypertensive encephalopathy; hypertension emergencies

Arterial Hypertens. 2021, vol. 25, no. 2, pages: 88-91

DOI: 10.5603/AH.a2021.0008

\section{Case report}

A 75-year-old female patient with uncontrolled high blood pressure, a history of hypertension secondary to chronic kidney disease, after unilateral nephrectomy due to cancer (clear cell renal cell carcinoma), remaining renal artery stenosis, all of which superimposed on long-lasting essential hypertension, and a suspicion of central nervous system (CNS) glioblastoma, was admitted to our Clinic after a convulsive episode. Blood pressure (BP) at admission was $254 / 98 \mathrm{~mm} \mathrm{Hg}$ and the heart rate 38/min. Upon physical examination a residual left hemiparesis and left sided ataxia was evident. Standard electrocardiography and heart ultrasonography showed left ventricular (LV) hypertrophy and the impaired LV relaxation. Laboratory tests were consistent with the diagnosis of CKD; additionally, microcytic anemia and substantially elevated levels of NT-pro-BNP were documented (see Tab. 1).

24-hour blood pressure monitoring showed mean 24-h systolic BP at $204 \mathrm{~mm} \mathrm{Hg}$ and diastolic BP at $83 \mathrm{~mm} \mathrm{Hg}$ (range from 156/71 to 239/94 mm Hg).

Address for correspondence: Marta Soltysiak, M.D., Ph.D., Department of Internal Diseases, Hypertension Unit, Municipal Hospital, Copernicus PL, ul. Nowe Ogrody 1-6, Gdańsk; e-mail: msoltysiak@copernicus.gda.pl

This article is available in open access under Creative Common Attribution-Non-Commercial-No Derivatives 4.0 International (CC BY-NC-ND 4.0) license, allowing to download articles and share them with others as long as they credit the authors and the publisher, but without permission to change them in any way or use them commercially 
Table 1. Clinical and biochemical baseline characteristics

\begin{tabular}{|l|c|}
\hline Clinical parameters & Value \\
\hline Office systolic BP $[\mathrm{mm} \mathrm{Hg}]$ & 254 \\
\hline Office diastolic BP $[\mathrm{mm} \mathrm{Hg}]$ & 98 \\
\hline Mean office BP $[\mathrm{mm} \mathrm{Hg}]$ & 150 \\
\hline Height $[\mathrm{cm}]$ & 164 \\
\hline Weight $[\mathrm{kg}]$ & 71 \\
\hline BMl $\left[\mathrm{kg} / \mathrm{m}^{2}\right]$ & 26.4 \\
\hline Biochemical parameters & \\
\hline Creatinine $[\mathrm{mg} / \mathrm{dL}]$ & 2.68 \\
\hline eGFR $\left[\mathrm{mL} / \mathrm{min} / 1.73^{2}\right]$ & 17 \\
\hline Hemoglobin $[\mathrm{g} / \mathrm{dL}]$ & 10 \\
\hline Na $[\mathrm{mmol} / \mathrm{L}]$ & 145 \\
\hline K [mmol/L] & 5.6 \\
\hline NT-pro-BNP $[\mathrm{pg} / \mathrm{mL}]$ & 2865 \\
\hline
\end{tabular}

$\mathrm{BP}$ - blood pressure; $\mathrm{BMI}$ - body mass index; eGFR — estimated glomerular filtration rate; NA — sodium; K — potassium; NT-pro-BNP — N-terminal pro b-type natriuretic peptide

CNS magnetic resonance imaging (MRI) revealed an extensive edema of vascular origin in the white matter of the following areas: right parietal, right temporal and right occipital lobes with positive mass effect, partial compression of the right lateral ventricle and midline shift up to $8 \mathrm{~mm}$ (Fig. 1). Furosemide and corticosteroids were administered to control cerebral edema. Given comorbid CKD and renovascular stenosis the choice of suitable and effective blood-lowering drug combination was challenging as it was substantially limited to only few drug classes. During the hospitalization, blood pressure was managed with IV. urapidil (BP-driven dosing), supplemented with oral methyldopa $(0.5 \mathrm{~g}$ qid), clonidine $(75 \mu \mathrm{g}$ tid $)$, nitrendipine $(0.02 \mathrm{~g}$ bid $)$ and doxazosine $(0.008 \mathrm{~g}$ bid $)$, which facilitated BP control at mean ambulatory BP level of 160/80 mm Hg. A partial resolution of neurological dysfunction was evident subsequent to BP lowering. Following interdisciplinary medical consultancy, based on both available evidence including advanced neoplasmatic disease and unstable clinical condition, the patient was disqualified from neuroanesthesia and oncological treatment, as well as from renal artery angioplasty. Patient was transferred to palliative care at the hospice facility.

\section{Discussion}

In the presented case, there were several therapeutic challenges including defining the targets for systemic $\mathrm{BP}$ as well as ensuring the effective BP control.

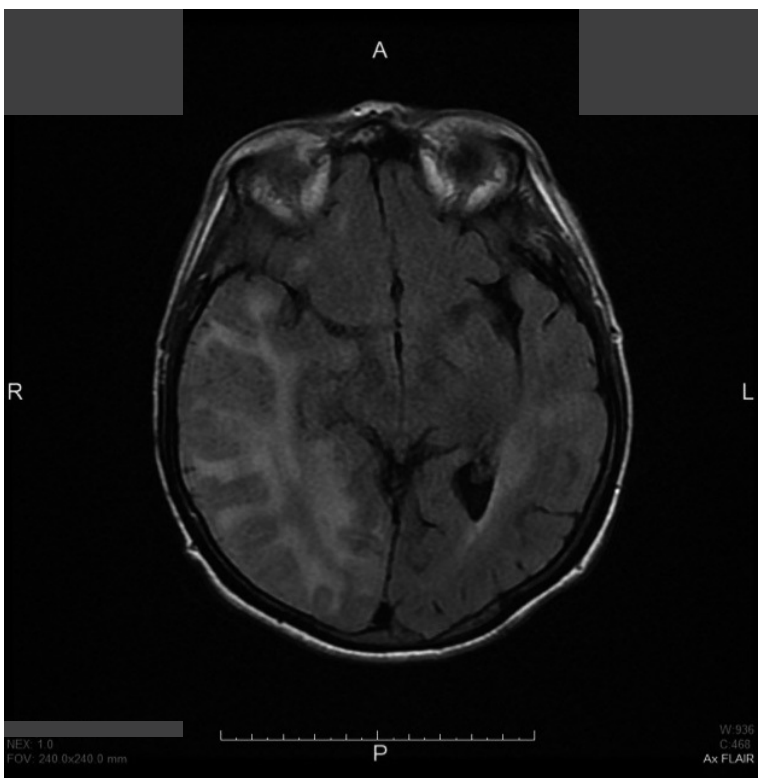

Figure 1. Magnetic resonance imaging of the brain at admission

According to the current European Societies of Hypertension, and Cardiology (ESH-ESC), and Polish Society of Hypertension (PTNT) guidelines, management of high BP-related emergencies is determined by comorbidities and may include either the most careful reduction of $\mathrm{BP}$ in case of acute stroke or immediate substantial reduction of BP in acute pulmonary edema or aorta dissection. In majority of clinical cases of hypertension emergencies and urgencies, a prompt BP lowering is required, for a maximum of $25 \%$ of initial BP within the first hours by means of both oral and parenteral antihypertensive drugs $[1,2]$. There are no large-scale randomized clinical trials evaluating different therapeutic strategies in hypertension emergencies, including CNS acute, subacute, or chronic failure $[2,3]$. Blood pressure, intracranial pressure (ICP), and cerebral blood flow $(\mathrm{CBF})$ remain in a complex mutual neurophysiological relationship mediated by extracranial and intracranial factors [4]. CBF autoregulation is ensured by complementary mechanisms such as metabolic and neurogenic (chemoreceptor- and baroreceptor-mediated) and myogenic factors, the latter effective only when cerebral perfusion pressure $(\mathrm{CPP})$ is maintained and controlled by carotid-located baroreceptors $[4,5]$.

We were not able to precisely define causality between CNS mass, and the extent of an increased ICP, as high systemic BP could also contribute. It was reasonable to deliberate whether high systemic $\mathrm{BP}$ confer CNS edema, thus blood pressure lowering could result in brain edema reduction which might 
translate to CNS dysfunction alleviation. Partial withdrawal of the neurological symptoms following systemic BP fall actually confirmed our assumption (ex juvantibus). In fact, hypertensive encephalopathy, first described by Oppenheimer and Fishberg, includes a complex of acute, and more importantly potentially reversible, neurological symptoms resulting from an increase of systemic blood pressure [6, 7]. High blood pressure, its' sudden increase and high variability are considered contributory to cerebral perfusion breakdown and blood-brain barrier damage with subsequent CNS dysfunction exacerbation. Hypertensive encephalopathy is usually a multifactorial condition - most often secondary to arterial hypertension, but also described in the late stage of pregnancy intoxication, hemolytic uremic syndrome, thrombotic thrombocytopenic purpura, chronic kidney disease, systemic diseases and as a consequence of treatment with cyclosporin A, calcineurin inhibitors, interferon alpha, or even digoxin [8-10]. In the presented case, the main cause of ICP increase and cerebral edema was probably due to glioblastoma, but the contribution of renal artery stenosis and secondary uncontrolled hypertension could not be excluded, as previously described by Sharer et al. [11]

CNS vasoconstriction caused by a rapid BP-rise which results in cerebral ischemia due to endothelial cells damage and intra-arterial thrombosis with consequent occurrence of cytotoxic edema was confirmed by angiography and SPECT-based case studies [12-15].

Another abnormality, which was not easy to explain and address was heightened levels of natriuretic peptide (Tab. 1). The possible reason for elevated B-type NP include: comorbid heart failure (HFpEF), chronic kidney disease, central nervous system malignancy itself, and/or hypertensive encephalopathy [16-19].

Our patient was also diagnosed with long-standing hypertension. Today, chronic hypertension may be easily managed by the combination therapy with RAAS blockers as the core together with thiazide/thiazide-like diuretics and/or calcium channel blockers as add-ons, preferably in single pill combination (SPC). Such drug combination especially in SPC formulation is capable of effectively controlling of roughly $85 \%$ hypertensive population (beta-blocker may be added based on multiple coexisting conditions) $[1,2]$. However, in the presented case, we faced several contraindications to the guideline-recommended treatment with RAAS blockers, beta-blockers, and several diuretics' classes, i.e.: the only remaining, kidney, renal artery stenosis, decreased creatinine clearance and reflex bradycardia secondary to cerebral edema. Given that patient was disqualified from renal artery angioplasty her hypertension could be managed only with less commonly used oral agents, which allowed to control BP within limited extent.

\section{References}

1. Williams B, Mancia G, Spiering W, et al. 2018 ESC/ESH Guidelines for the management of arterial hypertension: The Task Force for the management of arterial hypertension of the European Society of Cardiology (ESC) and the European Society of Hypertension (ESH). Eur Heart J. 2018; 39(33): 3021-3104, doi: https://doi.org/10.1093/eurheartj/ehy339.

2. Tykarski A, Filipiak K, Januszewicz A, et al. 2019 Guidelines for the Management of Hypertension - Part 1-7. Arterial Hypertension. 2019; 23(2): 41-87, doi: 10.5603/ah.a2019.0008

3. Wytyczne Grupy Ekspertów Sekcji Chorób Naczyniowych Polskiego Towarzystwa Neurologicznego. Pol J Neurol Neurosurg. 2012; 46(Suppl. 1).

4. Wiśniewski K, Bryl M, Bobeff EJ, et al. Ciśnienie śródczaszkowe a mózgowy przepływ krwi. Pol Przegl Neurol. 2017; 14(2): 57-62.

5. Moss E. The cerebral circulation. BJA CEPD Rev. 2001; 1(3): 67-71, doi: 10.1093/bjacepd/1.3.67.

6. Oppenheimer BS. Hypertensive encephalopath. Arch Int Med. 1928; 41(2): 264, doi: 10.1001/archinte.1928.00130140126010.

7. Vaughan CJ, Delanty N. Hypertensive emergencies. Lancet. 2000; 356(9227): 411-417, doi: 10.1016/s0140-6736(00)02539-3, indexed in Pubmed: 10972386.

8. Stott VL, Hurrell MA, Anderson TJ. Reversible posterior leukoencephalopathy syndrome: a misnomer reviewed. Intern Med J. 2005; 35(2): 83-90, doi: 10.1111/j.1445-5994.2004.00750.x, indexed in Pubmed: 15705136.

9. Striano P, Striano S, Tortora F, et al. Clinical spectrum and critical care management of posterior reversible encecphalopathy syndrome (PRES). Med Sci Monit. 2005; 11: 549-553, indexed in Pubmed: 16258402.

10. Vora J, Cooper J, Thomas JP. Polyarteritis nodosa presenting with hypertensive encephalopathy. Br J Clin Pract. 1992; 46(2): 144-145, indexed in Pubmed: 1360808.

11. Schärer K, Benninger $\mathrm{C}$, Heimann $\mathrm{A}$, et al. Involvement of the central nervous system in renal hypertension. Eur J Pediatr. 1993; 152(1): 59-63, doi: 10.1007/BF02072518, indexed in Pubmed: 8444207.

12. Garg RK. Posterior leukoencephalopathy syndrome. Postgrad Med J. 2001; 77(903): 24-28, doi: 10.1136/pmj.77.903.24, indexed in Pubmed: 11123390.

13. Truwit CL, Denaro CP, Lake JR, et al. MR imaging of reversible cyclosporin A-induced neurotoxicity. AJNR Am J Neuroradiol. 1991; 12(4): 651-659, indexed in Pubmed: 1882738.

14. Ito Y, Niwa H, Iida T, et al. Post-transfusion reversible posterior leukoencephalopathy syndrome with cerebral vasoconstriction. Neurology. 1997; 49(4): 1174-1175, doi: 10.1212/ wnl.49.4.1174, indexed in Pubmed: 9339716.

15. Tajima Y, Isonishi K, Kashiwaba T, et al. Two similar cases of encephalopathy, possibly a reversible posterior leukoencephalopathy syndrome: serial findings of magnetic resonance imaging, SPECT and angiography. Intern Med. 1999; 38(1): 54-58, doi: 10.2169/internalmedicine.38.54, indexed in Pubmed: 10052744 .

16. McCullough PA. B-type natriuretic peptides. A diagnostic breakthrough in heart failure. Minerva Cardioangiol. 2003; 51(2): 121-129, indexed in Pubmed: 12783068.

17. Bunevicius A, Deltuva V, Laws ER, et al. Preoperative N-terminal pro-B-type natriuretic peptide concertation and prognosis of 
brain tumor patients: a 5-year follow up study. Sci Rep. 2017; 7(1): 14775, doi: 10.1038/s41598-017-15394-6, indexed in Pubmed: 29116209.

18. Vickery S, Price CP, John RI, et al. B-type natriuretic peptide (BNP) and amino-terminal proBNP in patients with CKD: relationship to renal function and left ventricular hypertrophy.
Am J Kidney Dis. 2005; 46(4): 610-620, doi: 10.1053/j. ajkd.2005.06.017, indexed in Pubmed: 16183415.

19. Maraghi SEl, Yahia H, Heikal A, et al. B-type natriuretic peptide in hypertensive crises: Diagnostic use in hypertensive urgencies and emergencies. Egypt J Crit Care Med. 2013; 1(2): 61-67, doi: 10.1016/j.ejccm.2013.01.002. 